\title{
Mobilisasi Sumberdaya dalam Gerakan Literasi (Studi Pada Gerakan Vespa Pustaka)
}

\author{
Oleh: Luna Febriani, S.Sos., M.A
}

\begin{abstract}
ABSTRAK
Perilaku literasi merupakan upaya memanfaatkan informasi dari bahan bacaan untuk menjawab beragam persoalan kehidupan manusia sehari-hari, dalam artian ini perilaku literasi bukan sekedar membaca, tapi menulis dan memanfaatkan informasi juga. Di Indonesia, perilaku literasi berada dalam posisi yang memprihatinkan. Dari data yang ada, Indonesia menempati peringgkat ke 60 dari 61 negara di dunia terkait perilaku literasi. Rendahnya perilaku literasi di Indonesia ini menjadikan beberapa kelompok masyarakat maupun individu untuk melakukan gerakan dalam rangka meningkatkan perilaku literasi. Salah satunya adalah gerakan Vespa Pustaka, gerakan ini merupakan gerakan literasi yang diinisasi oleh pemuda di Kabupaten Bangka Selatan. Uniknya, gerakan ini dilakukan dengan cara menyelenggarakan perpustakaan jalanan di Toboali, Kabupaten Bangka Selatan dengan menggunakan sarana motor vespa. Penelitian ini ditujukan untuk melihat bagaimana gerakan ini dapat eksis dan diterima oleh masyarakat di kabupaten Bangka Selatan atau dengan kata lain mobilisasi apa saja yang digunakan oleh Vespa Pustaka dalam melakukan gerakan literasi ini. Dalam membedah penelitian ini digunakan teori mobilisasi sumber daya. Sehingga, dapat dilihat bentuk mobilisasi sumber daya yang digunakan oleh Vespa Pustaka dalam melakukan gerakannya,
\end{abstract}

Kata Kunci: Literasi, mobilisasi, gerakan, pemuda

\section{A. Pendahuluan}

Perilaku literasi di Indonesia berada dalam posisi yang memprihatinkan. Berdasarkan data yang didapatkan, peringkat literasi Indonesia berada pada posisi kedua terbawah atau peringkat 60 dari 61 negara yang diteliti oleh Central Connecticut State University (2015). Fakta ini juga didukung oleh survei yang yang dilakukan oleh BPS mengenai minat baca dan menonton anak-anak Indonesia yang menyatakan bahwa hanya 17,66\% anak-anak Indonesoa yang memiliki minat baca, sementara itu sebesar 91, 76\% anak-anak Indonesia memiliki minat menonton (http://www.femina.co.id/trendingtopic/peringkat-literasi-indonesia-nomor-duadari-bawah).

Hasil penelitian diatas menunjukkan bahwa perilaku literasi di Indonesia terbilang kecil. Perilaku literasi merupakan upaya memanfaatkan informasi dari bahan bacaan untuk menjawab beragam persoalan kehidupan manusia sehari- hari. Dengan kata lain, perilaku literasi merupakan suatu kontinum, yakni mulai dari kemampuan membaca; kemudian membaca dan menulis, diteruskan membaca menulis dan berbahasa dan akhirnya membaca menulis berpikir kritis dan berbahasa lisan yang dimanfaatkan untuk belajar sepanjang hayat baik dirumah, ditempat kerja maupun dalam masyarakat (Suyono, 82).

Untuk meningkatkan perilaku literasi masyarakat Indonesia, Pemerintah Republik Indonesia melalui Kementrian Pendidikan dan Kebudayaan mengembangkan Gerakan Literasi Sekolah (GSL). Gerakan ini dilakukan dengan cara membaca buku nonpelajaran selam 15 menit sebelum waktu belajar dimulai. Kegiatan ini dilakukan untuk menumbuhkan minat baca peserta didik serta meningkatkan keterampilan membaca agar pengetahuan dikuasai secara lebih baik. Selain muncul gerakan literasi yang diinisiasi oleh pemerintah, muncul pula gerakan dan organisasi yang digagas oleh beberapa 
kelompok masyarakat maupun individu untuk dapat menggiatkan perilaku literasi. Salah satunya adalah gerakan literasi Vespa Pustaka yang berlokasi di Toboali, Kabupaten Bangka Selatan.

Gerakan literasi Vespa Pustaka merupakan gerakan literasi yang diinisiasi oleh kelompok pemuda-pemuda yang ada di Toboali, Kabupaten Selatan. Pemuda merupakan Pemuda adalah individu yang bila dilihat secara fisik sedang mengalami perkembangan dan secara psikis sedang mengalami perkembangan emosional, sehingga pemuda merupakan sumber daya manusia pembangunan baik saat ini maupun masa datang. Menurut Undang-Undang No. 40 tahun 2009 Pemuda adalah warga negara Indonesia yang memasuki periode penting pertumbuhan dan perkembangan yang berusia 16 (enam belas) sampai 30 (tiga puluh) tahun. Definisi yang kedua, pemuda adalah individu dengan karakter yang dinamis, bahkan bergejolak dan optimis namun belum memiliki pengendalian emosi yang stabil

Sejarah bangsa Indonesia tidak dapat dilepaskan dari gerakan-gerakan yang diinisiasi oleh pemuda. Kehadiran gerakan pemuda yang sarat nilai dan diapresiasi oleh lapisan masyarakat inilah, yang kemudian harus dikembangkan sedemikian rupa. Sehingga pergerakan bangsa menjadi semakin dinamis, dan perbaikan kehidupan bernegara dalam setiap dimensi kehidupan selalu berkesinambungan (Dewanata, 2008: 139)

Kemunculan Vespa Pustaka yang merupakan gerakan literasi Vespa Pustaka ini tidak dapat dilepaskan dari rendahnya perilaku literasi di Kabupaten Bangka Selatan,. Selain itu, minimnya akses dan ruang untuk masyarakat dalam mengakses buku atau bahan bacaan menjadikan dasar dari gerakan literasi pemuda ini. Hadirnya gerakan literasi Vespa Pustaka mendapatkan respon positif oleh masyarakat sekitar, sehingga hingga saat ini di usianya yang menginjak 3 tahun kehadiran Vespa Pustaka tetap mendapatkan ruang dalam masyarakat sehingga sampai saat ini gerakan literasi masih tetap ada dan berkembang. Oleh karena itu, penelitian ini ditujukan untuk mencari tahu bagaimana Vespa Pustaka mengembangkan gerakan literasinya, atau dengan kata lain sumberdaya apa saja yang digunakan gerakan literasi Vespa Pustaka sehingga mereka dapat bertahan dan berkembang hingga saat ini.

\section{B. Rumusan Masalah}

Adapun rumusan masalah dalam penelitian ini adalah "Bagaimana mobilisasi sumberdaya yang dilakukan Vespa pustaka dalam mengembangkan gerakan Vespa Pustaka?

\section{Kerangka Teoritis}

Dalam mengkaji tulisan ini, peneliti menggunakan salah satu jenis teori dari teori gerakan sosial yakni teori mobilisasi sumber daya. Menurut Giddens (gerakan sosial merupakan upaya kolektif untuk mengejar suatu kepetingan bersama, atau mencapai tujuan bersama melalui tindakan kolektif (collective action) di luar lingkup lembaga-lembaga yang mapan (Suharko, 2014:15). Konsep dan teori tentang Gerakan Sosial mengalami perkembangan pesar pada dekade 60an dan semakin kaya memasuki abd ke-21.

Teori mobilisasi sumber daya manusia merupakan salah satu bagian teori dari teori gerakan sosial baru. Munculnya gerakan sosial baru ditandai dengan semakin beragamnyapelaku gerakan sosial seperti mahasiswa/i, kalaangan profesional, perempuan dan tidak lagi menjadi fortopolio buruh dan petani dan juga isu yang hendak dicapai seperti hak asasi manusia, demokratisasi, perempuan, lingkungan hidup, ketidakadilan membuat studi gerakan sosial bergeser, dari terpusat menjadi menyebar ke berbagai pusat-pusat disiplin ilmu baik dikalangan akademisi maupun pelaku perubahan (Situmorang, 2013: 10)

Secara umum, studi-studi gerakan sosial di Indonesia banyak mengacu pada kerangka teoritis dari pandangan Rajendra Singh, yang mana menurut Singh peta teori gerakan sosial 
terdiri dari: (1) Klasik, (2) neo-klasik dan (3) Gerakan Sosial Baru (Sukmana, 2016: 8). Classical social movements meliputi studi tentang perilaku kolektif seperti kerumunan, kerusuhan dan penolakan yang berbasis pada akar psikologi sosial klasik. Sementara, tradisi neo klasik dihubungkan dengan teori gerakan sosial lama yang mana teori memiliki dua model, yaitu fungsional dan dialektika Marxis. Sedangkan teori gerakan sosial baru atau gerakan sosial kontemporer memiliki cara pandang tersendiri tentang logika dari tindakan yang berbasis dalam politik, ideologi, kultur, etnisitas, jender dan seks sebagai akar dari tindakan-tindakan kolektif. Sedangkan teori gerakan sosial lama menganggap bahwa hal yang paling penting dari aktor sosial didefiniskan oleh relasi-relasi kelas yang berakar dalam proses produksi dan identitas sosial lainnya yang memberntuk aktor-aktor kolektif (Sukmana, 2015: 118).

Tulisan tentang pemuda dan gerakan literasi ini akan dibedah dengan teori mobilisasi sumberdaya yang diperkenalkan oleh Anthony Oberschall. Teori mobilisasi sumberdaya memfokuskan perhatiannya pada proses-proses sosial yang memungkinkan muncul dan berhasilnya suatu gerakan. Teori ini berasumsi bahwa faktor penting kelompok melakukan mobilisasi karena memiliki jaringan komunikasi yang sudah mapan, terdapatnya anggota dengan kemapanan kepemimpinan dan adanya partisipasi tradisional dari anggotanya. Selain itu, dalam kelompok juga terdapat pemimpin, anggora, terdapat pertemuan, kegiatan rutin, rantai sosial, dan berbagai kepercayaan, simbol serta bahasa yang sama.

Sehingga, secara sederhana dapat disimpulkan bahwa faktor-faktor determinan dalam suatu gerakan sosial menurut teori mobilisasi sumberdaya, yakni:

1. Organisasi gerakan sosial, merupakan sistem nilai bersama, perasaan dari komunitas, norma tindakan dan struktur organisasi.

2. Pemimpin dan kepemimpinan, pemimpin didefinisikan sebagai pembuat keputusan strategis yang menginspirasi dan mengorganisais orang lain untuk ber- partisipasi, sedangkan kepemimpinan adalah kemampuan untuk mempengaruhi kelompok melalui pencapaian tujuan.

3. Sumberdaya dan mobilisasi sumberdaya, terdapat lima tipe sumberdaya dalam gerakan sosial, yakni: sumberdaya moral, sumberdaya kultural, sumberdaya organisasi sosial, sumberdaya manusia dan sumberdaya material,

4. Jaringan dan partisipasi, jaringan sosial merupakan faktor pelekat bagi sebagian besar anggora dalam berbagai organisasi.

5. Peluang dan kapasitas masyarakat.perspektif ini mengacu pada kemampuan masyarakat lokal untuk mengorganisir suatu tindakan kolektif.

Teori mobilisasi sumberdaya diatas akan melihat sejauh mana gerakan yang dilakukan oleh Vespa Pustaka di Kabupaten Bangka Selatan dapat diterima oleh asyarakat dan dapat bertahan hingga sekarang ini.

\section{Metode Penelitian}

Penelitian ini menggunakan metode penelitian kualitatif dengan pendekatan riset naratif. Czarniawska (dalam Craswell) mendefinisikan riset naratif sebagai tipe sedain kualitatif yang spesifikyang narasinya dipahami sebagai teks yang dituturkan atau dituliskan dengan menceritakan tentang peristiwa/aksi atau rangkaian peristiwa. aksi, yang terhubung secara kronologis (Craswell, :201596). Prosedur pelaksanaan riset ini dimulai dengan memfokuskan pada pengkajian terhadap satu atau dua individu dan penyusuna kronologis atas makna dari pengalaman tersebut.

Dalam mengumpulkan data, peneliti menggunakan metode pengumpulan data dengan cara wawancara, pengamatan, dokumen-dokumen terkait, gambar dan sumber data kualitatif lainnya. Data yang telah dikumpulkan kemudian akan dianalisis secara sistematis, yakni dengan menggunakan metode analisis data interaktif Miles dan Huberman yang terdiri dari (Idrus, 2002):

1. Reduksi data merupakan tahap pemilihan, 
pemusatan perhatian pada penyederhanaan, pengabstrakan dan transformasi data kasar yang muncul dari catatan-catatan tertulis dari lapangan

2. Penyajian data merupakan tahap penyusunan informasi yang memberikan kemungkinan adanya penrikan kesimpulan dan pengambilan tindakan.

3. Penarikan kesimpulan merupakan proses akhir dimana terjadi penarikan arti atau makna dari data yang telah ditampilkan.

\section{E. Hasil dan Pembahasan}

Perilaku literasi di Indonesia menempati posisi yang memprihatinkan, berdasarkan data yang ada perilaku literasi Indonesia menempati possisi ke 60 dari 61 negara di dunia. Rendahnya perilaku literasi ini kemudian menjadikan beberapa kelompok masyarakat dan individu membentuk dan menggiatkan gerakan-gerakan literasi, salah satunya adalah gerakan Vespa Literasi. Vespa Pustaka merupakan salah satu gerakan literasi yang ada di Provinsi Kepualauan Bangka Belitung, tepatnya di Kabupaten Bangka Selatan. Kabupaten Bangka Selatan merupakan salah satu kabupaten yang ada di Provinsi Kepulauan Bangka Belitung dengan Toboali sebagai ibukotanya.

Kelahiran gerakan Vespa Pustaka ini diinisiasi oleh salah seorang pemuda dari Toboali, yakni Agam Primadi. Dibentuknya gerakan literasi Vespa Pustaka didasari oleh beberapa hal, yakni:

1. Untuk mengatasi persoalan minimnya perilaku literasi di Indonesia, khususnya di Kabupaten Bangka Selatan. Bangka Selatan termasuk dalam Kabupaten yang rendah akan tingkat literasinya.

2. Untuk memberikan ruang membaca kepada masyarakat di Kabupaten Bangka Selatan umumnya dan Toboali khususnya karena selama ini di Kabupaten Bangka Selatan masih minimnya ruang membaca bagi masyarakat. Selain tidak adanya ruang untuk membaca bagi masyarakat, sulitnya akses untuk mendapatkan buku-buku bacaan dikarenakan buku-buku yang harganya relatif tinggi juga mendasari lahirnya gerakan Vespa Pustaka.

Alasan tersebut menjadikan Agam sebagai pemuda Bangka Selatan untuk menggagas rumah baca bagi masyarakat di Kabupaten Bangka Selatan, sehingga berawal dari perpustakaan pribadi yang dimilikinya ia kemudian membentuk rumah baca yang dibuka bagi masyarakat umum. Kemunculan rumah baca ini mendapatkan respon baik bagi masyarakat, karena setidaknya telah ada ruang bagi masyarakat untuk mendapatkan bahan-bahan bacaan. Selain mendapatkan respon baik dari maysarakat, kemunculan rumah baca ini juga menjadi wadah bagi masyarakat untuk menyalurkan buku-buku mereka untuk dapat dibaca oleh masyarakat banyak.

Adanya respon yang baik dari masyaakat ini kemudian menjadikan sang penggiatnya untuk memperbesar dan memperluas jaringan rumah baca. Oleh karena itu, di tahun 2014 penggiat rumah baca komunitas ini melakukan penjajakan dengan beberapa pengendara sepeda motor jenis vespa yang tergabung dalam komunitas Scooter Toboali di Toboali, Kabupaten Bangka Selatan. Penjajakan ini dilakukan untuk memperluas akses rumah baca komunitas agar seluruh element masyarakat yang ada di Kabupaten Bangka Selatan dapat menikmati fasilitas dan merasakan manfaat dari kehadiran rumah baca ini. Kerjasama ini kemudian disambut baik oleh para pengendara motor vespa yang tergabung dalam Scooter Toboali, yang kemudian tepat pada tanggal 8 Mei 2015 terbentuklah gerakan literasi yang diberi nama Vespa Pustaka.

Seiring tebentuknya Gerakan Vespa Pustaka, maka dibentuk pula struktur organisasi kepengurusannya. Dibentuknya struktur organisasi ini untuk memudahkan dan memperjelas pembagian kerja para anggota dan untuk melegalisasi kegiatan-kegiatan yang dilakukan oleh Vespa Pustaka. Organisasi ini diketua oleh penggiat dari gerakan Vespa Pustaka itu sendiri dan memiliki 23 anggota yang mana anggotaanggota tersebut juga merupakan anggota 
Scooter Toboali. Pelibatan pengendara Vespa dalam melakukan gerakan literasi dikarenakan beberapa hal, yakni:

1. Anggota pengendara vespa merupakan pemuda-pemuda yang memiliki semangat tinggi dan enerjik

2. Untuk mengisi waktu luang para pengendarapengendara vespa, karena selama ini pengendara vespa dianggap hanya

3. Untuk mengubah image atau citra para pengendara vespa yang selama ini cenderung dipandang negatif oleh masyarakat sekitar. Dengan melibatkan para pengendara vespa ini diharapkan image masyarakat terhadap pengendara motor vespa menjadi positif.

Dalam melakukan gerakannya, ada beberapa kegiatan rutin yang diselenggarakan oleh gerakan Vespa Pustaka, yakni; rumah baca, literasi jalanan, serta diskusi-diskusi tematik. Rumah baca Vespa Pustaka merupakan perpustakaan bagi masyarakat yang hendak meminjam dan membaca buku-buku yang disediakan. Rumah baca ini memiliki koleksi 1500an yang terdiri dari buku sosial, psikologi, ekonomi, motivasi , seri remaja dan anak-anak. Rumah baca ini dibuka setiap hari dari mulai pukul 15.00 s.d 17.45 WIB. Untuk literasi jalanan dilakukan oleh Vespa Pustaka dengan cara membuka lapak atau perpustakan buku di jalanan. Perpustakaan jalanan ini dilakukan dalam waktu 3-4 kali dalam seminggu dan bertempat di depan jan Gedung Nasional, Toboali. Sedangkan untuk diskusi tematik dilakukan di rumah baca sesuai dengan tema-tema yang sedang berkembang.

Gerakan Vespa Pustaka yang digagas oleh pemuda-pemuda Vespa di Toboali Kabupaten Bangka Selatan mendapat tanggapan atau respon positif bagi masyarakat sekitar. Hal ini terlihat dari antusias masyarakat untuk mengunjungi rumah baca dan perpustakaan jalanan yang digerakkan oleh Vespa Pustaka. Keberhasilan dalam melakukan gerakan literasi oleh Vespa Pustaka tidak dapat dilepaskan dari kemampuan gerakan tersebut dalam memobilisasi sumberdaya yang sifatnya internal maupun eksternal yang ada dalam lingkungan masyarakat sekitar. Menurut McCarthy dan Zald (dalam Sukmana 2010:157) menyatakan bahwa perkembangan gerakan sosial dipandang sebagai produk dari kekuatan-kekuatan lingkungan baik bersifat internal maupun eksternal. Faktorfaktor internal meliputi: kepemimpinan, tingkat ketersediaan sumberdaya, ukuran kelompok dan tingkat organisasi internal. Sedangkan faktorfaktor eksternal meliputi: tingkat represi dari masyarakat, tingkat simpatisan eksternal, serta jumlah dan kekuatan kelompok politik.

Dari paparan diatas, maka dapat dirumuskan faktor-faktor yang mempengaruhi keberhasilan gerakan Vespa Pustaka antara lain:

\section{Organisasi Gerakan Sosial}

Menurut McLaughlin (Sukmana, 2016) karateristik yang menonjol dari suatu gerakan sosial adalah meliputi adanya sistem nilai bersama, perasaan dari komunitas, norma tindakan dan struktur organisasi. Faktor organisasi gerakan sosial merupakan faktor yang mempengaruhi dalam gerakan literasi Vespa Pusta, dimana di dalam gerakan ini dibangun sebuah organisasi dengan struktur yang jelas dan didalammya terdapat sistem nilai bersama, perasaan dari komunitas serta norma dan tindakan. Sistem nilai bersama yang dimiliki dan dijaga oleh Vespa Pustaka adalah nilai kepercayaan dan kesukarelaan. Nilai kepercayaan mengacu pada adanya rasa percaya terhadap sesama anggota komunitas serta para peminjam buku. Untuk nilai kesukarelaan dapat dilihat dari anggotaanggota yang terlibat dalam gerakan literasi Vespa Pustaka merupakan para sukarelawan yang tidak dibayar, bahkan mereka harus iuran setiap bulannya untuk menjamin keberlangsungan gerakan literasi ini. Hal inilah yang kemudian menjadikan mereka dapat menjaga soliditas antara sesama, karena hubungan yang terjalin dalam gerakan literasi Vespa Pustaka bukan berdasarkan material, melainkan berdasarkan hubungan kekeluargaan. 
2. Pemimpin dan Kepemimpinan

Menurut Morris dan Staggenborg (Sukmana, 2016), para pemimpin sangat penting dalam gerakan sosial, mereka menginspirasi komitmen, memobilisasi sumber-sumber, menciptakan dan memahami kesempatan, menyusun strategi dan mempengaruhi hasil-hasil. Pemimpin gerakan di definisikan sebagai pembuat keputusan startegis yang menginspirasi dan mengorganisasi orang lain untuk berpartisipasi dalam gerakan sosial. Sedangkan kepemimpinan adalah kemauan untuk mempengaruhi kelompok melalui pencapaian tujuan. Dalam gerakan literasi Vespa Pustaka, pemimpin memiliki peranan penting dalam mengembangkan dan memajukan gerakan ini. Pemimpin gerakan Vespa Pustaka termasuk dalam dapat menginspirasi para anggota gerakan, serta dapat memobilisasi sumber-sumber yang ada untuk memajukan gerakan ini, seperti jaringan. Dimana, pemimpin gerakan Vespa Pustaka ini pernah menjadi pemuda pelopor yang mewakili pemuda Bangka Belitung ke Tingkat nasional, sehingga jaringan sudah banyak terbangun.

3. Sumberdaya dan Mobilisassi Sumberdaya Menurut Edwards dan McCarthy (Sukmana, 2016), terdapat lima sumberdaya yakni: sumberdaya moral, sumberdaya kultural, sumberdaya organisasi sosial, sumberdaya manusia dan sumberdaya material. Dalam melakukan dan mengembangkan gerakan literasi, gerakan Vespa Pustaka memanfaatkan sumberdayasumberdaya yang ada dalam lingkungan masyarakat sekitar. Sumberdaya moral disini merupakan dukungan-dukungan simpati dan dukungan orang atau tokoh-tokoh terkenal. Dukungan simpati ini dapat dilihat dari banyaknya donasi-donasi buku yang diberikan oleh masyarakat dalam rangka mendukung gerakan literasi. Selain itu gerakan literasi juga didukung oleh banyak pihak, baik yang berasal dari masyarakat maupun dari tokoh-tokoh birokrasi.

Kedua, sumberdaya kultural, dapat dilihat dari bagaimana gerakan ini memanfaatkan dan memiliki kompetensi atau pengetahuan khusus yang dapat menjadi nilai untuk suatu gerakan sosial. Dalam hal ini kompetensi kultural yang dimobilisasi oleh Vespa Pustaka adalah dengan cara melibatkan pemuda-pemuda daerah dalam menggerakkan organisasi dan kegiatan Vespa Pustaka. Dilibatkannya pemuda daerah menjadi nilai penting, karena pemuda merupakan orang yang masih memiliki kemauan dan semangat yang tinggi dalam menjalankan kegiatan organisasi. Keuntungan lainnya dengan melibatkan pemuda daerah adalah interaksi dengan pembaca atau pengunjung akan lebih mudah dan cepat dilakukan, karena berasal dari kebudayaan yang sama. Selain pelibatan pemuda daerah, mobilisasi kultural lainnya adalah dengan melakukan literasi dijalan, dimana gerakan Vespa Pusta aktif menjemput bola para pembaca yang tidak memiliki waktu luang untuk berkunjung ke rumah baca. Dengan melakukan literasi jalanan, maka mereka memanfaatkan ruang jalanan yang biasanya didatangi dan disukai anak-anak muda untuk menghabiskan waktunya, sehingga banyak anak muda yang tertarik dengan literasi jalanan yang digagas oleh Vespa Pustaka. Selain itu sumberdaya kultural yang digunakan oleh gerakan Vespa Pustaka adalah penggunaan media-media sosial yang digunakan untuk sarana promosi dan informasi kepada masyarakat luas tentang eksistensi dan kegiatan-kegiatan yang dilakukan oleh Vespa Pustaka.

Ketiga, sumberdaya organsasi sosial meliputi: jaringan sosial dan organsiassi. Gerakan literasi Vespa Pustaka memanfaatkan dan memobilisaisi sumberdaya ini untuk mengembangkan gerakannya, seperti pemanfaatan jaringan sosial. Tidak dapat dipungkiri Vespa Pustaka memiliki banyak 
jaringan dengan organisasi-organisasi baik dalam lingkup lokal maupun dalam lingkup luar, seperti KNPI, HIPMI, PBNU serta jaringan rumah baca yang ada diluar kota. Banyaknya jaringan sosial yang dimiliki oleh gerakan Vespa Literasi ini dirasakan dapat membantu keberlangsungan dan prasarana yang dibutuhkan, seperti barubaru ini Vespa Pustaka mendapat bantuan ratusan buku dari salah satu penerbit yang ada di Pulau Jawa. Selain bantuan buku, ada pula bantuan-bantuan lainnya yang bantuan dana dari Kementrian Pemuda dan Olahraga (Kemenpora) dan lain sebagainya.

Keempat, mobilisasi sumber daya manusia. Tidak dapat dipungkiri sumberdaya manusia lebih nyata dan lebih muda diapresiasi dibandingkan sumberdaya moral, sumberdaya kultural dan sumberdaya organisasi sosial. Mobilisasi sumberdaya manusia dapat dilihat dari kualitas sumberdaya manusia yang ada dalam gerakan tersebut dimana hampir sebagian besar sumberdaya manusia yang tergabung dalam gerakan Vespa Pustaka merupakan orang yang berpendidikan dan sedang menempuh pendidikan strata 1, bahkan ada pula yang sedang menempuh pendidikan strata 2, yakni ketua Vespa Pustaka. Sehingga, setiap anggota Vespa Pustaka memiliki kompetensi masing-masing sesuai dengan latar belakang pendidikan mereka.

Terakhir, sumberdaya material merupakan sumberdaya yang bersifat modal atau finansial. Sumber daya material merupakan bagian penting, karena dari sumbedaya ini eksintensi dapat berlangsung. Tidak dapat dipungkiri, dalam melakukan gerakan literasinya, hampir sebagian besar sumberdaya finansialnya dikeluarkan dari kantong pribadi ketua organisasi. Namun, selain dari bantuan uang pribadi pemimpin organsiasi, sumberdya finansial gerakan ini juga ditopang oleh iuran para anggotanya dimana setiap bulannya anggota diwajibkan untuk membayar iuran sebesar Rp. 20.000,- (dua puluh ribu rupiah). Iuran ini secara tidak langsung dapat membantu kegiatan operasional yang dilakukan oleh Vespa Pustaka.

Pendayagunaan mobilisasi sumberdaya seperti yang telah dipaparkan diatas menjadikan gerakan Literasi Vespa Pustaka ini dapat ada bertahan dan diterima oleh masyarakat. Mobilisasi sumberdaya merupakan pemanfaatan sumberdaya yang ada dilingkungan sekitar baik yang sifatnya internal maupun ekternal untuk mendukung dan mengembangkan suatu gerakan sosial. Selain mobilisasi sumberdaya diatas, masih banyak sumberdaya yang sesungguhnya dapat dikembangkan oleh gerakan Vespa Pustaka. Oleh karena itu diperlukan inventarisir sumberdaya dan strategi mobilisasi sumberdaya agar pemanfaatannya lebih optimal.

\section{F. Kesimpulan}

Dari hasil pengamatan yang dilakukan terhadap gerakan literasi Vespa Pustaka yang ada di Kabupaten Bangka Selatan, maka dapat ditarik kesimpulan bahwa keberadaan Vespa Pustaka mendapat respon positif dan antusias yang tinggi bagi masyarakat. Hal ini dikarenakan Vespa Pustaka memberikan ruang dan akses bagi masyarakat Toboali dan Bangka Selatan umumnya untuk dapat mebaca. Penerimaan masyarakat terhadap gerakan literasi Vespa Pustaka ini tidak dapat dilepaskan dari kemampuan gerakan literasi tersebut dalam memobilisasi sumberdaya yang ada. Mobilisasi sumberdaya merupakan pemanfaatan sumberdaya yang ada dilingkungan sekitar baik yang sifatnya internal maupun ekternal untuk mendukung dan mengembangkan suatu gerakan sosial.

Menurut McCarthy dan Zald (dalam Sukmana 2010:157) menyatakan bahwa perkembangan gerakan sosial dipandang sebagai produk dari kekuatan-kekuatan lingkungan baik bersifat internal maupun eksternal. Faktorfaktor internal meliputi: kepemimpinan, tingkat ketersediaan sumberdaya, ukuran kelompok dan 
tingkat organisasi internal. Sedangkan faktorfaktor eksternal meliputi: tingkat represi dari masyarakat, tingkat simpatisan eksternal, serta jumlah dan kekuatan kelompok politik. Adapun mobilisasi sumberdaya yang dilakukan oleh gerakan Vespa Pustaka antara lain:

1. Sumberdaya moral disini merupakan dukungan-dukungan simpati dan dukungan orang atau tokoh-tokoh terkenal. Dukungan simpati ini dapat dilihat dari banyaknya donasi-donasi buku yang diberikan oleh masyarakat dalam rangka mendukung gerakan literasi. Selain itu gerakan literasi juga didukung oleh banyak pihak, baik yang berasal dari masyarakat maupun dari tokohtokoh birokrasi.

2. Pemimpin dan Kepeminpinan

Menurut Morris dan Staggenborg, para pemimpin sangat penting dalam gerakan sosial, mereka menginspirasi komitmen, memobilisasi sumber-sumber, menciptakan dan memahami kesempatan, menyusun strategi dan mempengaruhi hasil-hasil. Pemimpin gerakan Vespa Pustaka (Agam Primadi) menurut para anggota kelompok Vespa Pustaka merupakan orang atau sosok pimpinan yang dapat menginspirasi para anggota gerakan, memiliki kompetensi akademik serta dapat memobilisasi sumbersumber yang ada untuk memajukan gerakan ini, seperti jaringan. Dimana, pemimpin gerakan Vespa Pustaka ini pernah menjadi pemuda pelopor yang mewakili pemuda Bangka Belitung ke Tingkat nasional, sehingga jaringan sudah banyak terbangun.

3. Sumberdaya dan Mobilisassi Sumberdaya

- Sumberdaya moral disini merupakan dukungan-dukungan simpati dan dukungan orang atau tokoh-tokoh terkenal. Dukungan simpati ini dapat dilihat dari banyaknya donasidonasi buku yang diberikan oleh masyarakat dalam rangka mendukung gerakan literasi. Selain itu gerakan literasi juga didukung oleh banyak pihak, baik yang berasal dari masyarakat maupun dari tokoh-tokoh birokrasi.
Sumberdaya kultural, dalam hal ini kompetensi kultural yang dimobilisasi oleh Vespa Pustaka adalah dengan cara melibatkan pemuda-pemuda daerah dalam menggerakkan organisasi dan kegiatan Vespa Pustaka. Dilibatkannya pemuda daerah menjadi nilai penting, karena pemuda merupakan orang yang masih memiliki kemauan dan semangat yang tinggi dalam menjalankan kegiatan organisasi. Kaum muda dianggap memiliki keunggulan dibandingkan kelompok sosial lain. Mereka lahir dari kelas menengah perkotaanyang memiliki modal sosial dan budaya dibandingkan kelompok sosial lainnya. Modal sosial seperti kemampuan teknologi informasi, keterampilan berjejaraing, serta prestasi akademik dan pendidikan telah memungkinkan mereka membangun kekuatan soal melalui gerakan sosial (Suharko $\mathrm{dkk}, 2014$; 24).

Keuntungan lainnya dengan melibatkan pemuda daerah adalah interaksi dengan pembaca atau pengunjung akan lebih mudah dan cepat dilakukan, karena berasal dari kebudayaan yang sama. Selain pelibatan pemuda daerah, mobilisasi kultural lainnya adalah dengan melakukan literasi dijalan, dimana gerakan Vespa Pusta aktif menjemput bola para pembaca yang tidak memiliki waktu luang untuk berkunjung ke rumah baca.

Ketiga, sumberdaya organsasisosialmeliputi: jaringan sosial dan organsiassi. Gerakan literasi Vespa Pustaka memanfaatkan dan memobilisaisi sumberdaya ini untuk mengembangkan gerakannya, seperti pemanfaatan jaringan sosial. Tidak dapat dipungkiri Vespa Pustaka memiliki banyak jaringan dengan organisasi-organisasi baik dalam lingkup lokal maupun dalam lingkup luar, seperti KNPI, HIPMI, PBNU serta jaringan rumah baca yang ada diluar kota.

Keempat, mobilisasi sumber daya manusia. Tidak dapat dipungkiri sumberdaya manusia lebih nyata dan lebih muda diapresiasi 
dibandingkan sumberdaya moral, sumberdaya kultural dan sumberdaya organisasi sosial. Mobilisasi sumberdaya manusia dapat dilihat dari kualitas sumberdaya manusia yang ada dalam gerakan tersebut dimana hampir sebagian besar sumberdaya manusia yang tergabung dalam gerakan Vespa Pustaka merupakan orang yang berpendidikan dan sedang menempuh pendidikan strata 1 , bahkan ada pula yang sedang menempuh pendidikan strata 2.

- Terakhir, sumberdaya material merupakan sumberdaya yang bersifat modal atau finansial. Sumber daya material merupakan bagian penting, karena dari sumbedaya ini eksintensi dapat berlangsung. Tidak dapat dipungkiri, dalam melakukan gerakan literasinya, hampir sebagian besar sumberdaya finansialnya dikeluarkan dari kantong pribadi ketua organisasi. Namun, selain dari bantuan uang pribadi pemimpin organsiasi, sumberdya finansial gerakan ini juga ditopang oleh iuran para anggotanya dimana setiap bulannya anggota diwajibkan untuk membayar iuran sebesar Rp. 20.000,(dua puluh ribu rupiah)

Pendayagunaan sumberdaya di lingkungan baik yang sifatnya internal maupun ekternal menjadikan faktor determinan dalam mempengaruhi perkembangan suatu gerakan sosial.

\section{G. Daftar Pustaka}

Creswell, John. 2014. Penelitian Kualitatif \& Desain Riset: Memilih di Antara Lima Pendekatan (Edisi 3). Yogyakarta: Pustaka Pelajar..

Dewanata Pandu dan Chavcay Syaifullah. 2008. Rekonstruksi Pemuda. Jakarta: Kementrian Negara Pemuda dan Olahraga.

Idrus, Muhammad. 2002. Metode Penelitian Ilmu Sosial Pendekatan Kualitatif dan Kuantitatif. Erlangga: Yogyakarta.

Situmorang, Abdul Wahib. 2013. Gerakan Sosial: Teori dan Praktik. Yogyakarta: Pustaka
Pelajar.

Suharko dkk, 2014. Organisasi Pemuda Lingkungan di Indonesia Pasca Orde Baru. Yogyakarta: Gadjah Mada University Press. Sukmana, Oman. 2016. Konsep dan Teori Gerakan Sosial. Malang: Instrans Publishing.

Sumber Internet:

http://www.femina.co.id/trending-topic/ peringkat-literasi-indonesia-nomor-duadari-bawah diunduh pada 6 Juni 2017 pukul 12.00 .

https://tirto.id/literasi-indonesia-yang-belummerdeka-bBJS diunduh pada 6 Juni 2017 pukul 10.04.

http://journal.um.ac.id/index.php/jip/article/ view/50/293 diunduh pada 6 Juni 2017 pukul 13.19. 